\title{
Havaintoja viron ja suomen paikallissijojen käytön eroista
}

\author{
EVE MIKONE \\ Turun yliopisto
}

Tiivistelmä. Artikkelissa verrataan viron ja suomen paikallissijojen käytön eroja. Tarkastelussa edetään viron ja suomen paikallissijoja yhdistävistä tekijöistä erottaviin tekijöihin. Ensin luodaan lyhyt katsaus viron ja suomen paikallissijojen ja sijasarjojen yhteiseen kehitykseen, jonka jälkeen tarkastellaan niiden asemaa ja erilliskehitystä kummassakin kielessä erikseen. Lopuksi tarkastellaan yksityiskohtaisemmin toimintaa ja toiminnan kohdetta kuvaavia rakenteita, joista virossa käytetään ulkopaikallissijoja ja suomessa sisäpaikallissijoja.

Avainsanat: kontrastiivinen kielentutkimus; kielihistoria; paikallissijat; lokaalisuuden ilmaiseminen; toiminnan ja toiminnan kohdetta kuvaavat rakenteet; viro; suomi

\section{Johdanto}

Viron ja suomen sijajärjestelmän niin kutsutut varsinaiset paikallissijat inessiivi, elatiivi, illatiivi, adessiivi, ablatiivi ja allatiivi ovat molemmissa kielissä samoja. Niillä on yhteinen kehityshistoria ja niiden keskeiset merkitystehtävät eivät poikkea toisistaan oleellisesti. Molemmissa kielissä paikallissijoilla on yhteisten merkitysten lisäksi sellaisia merkityksiä, jotka toisesta kielestä puuttuvat. Nämä ovat mielenkiintoisia tapauksia, kun pohditaan sukulaiskielten kehityksen vaihtoehtoja (mitä kaikkea voisi / olisi voinut olla), mutta pohtimisen aihetta anta- 
vat myös tapaukset, joissa viro ja suomi käyttävät samassa merkitystehtävässä eri sijasarjoja. Tässä artikkelissa kiinnitänkin huomion sellaisiin tapauksiin, mutta en kaikkiin, koska ryhmiä, joissa vastakkaisten sijasarjojen hyödyntämistä esiintyy, on paljon, ja koska ne ovat pieniä ja suljettuja. Eroja on runsaasti lähinnä lekseemitasolla. Mielenkiintoni sijajärjestelmien vastakkaista käyttöä kohtaan on virinnyt opiskelijoiden kysymyksistä, joille ei ole löytynyt tutkimuksista vastauksia.

\section{2. - ja $s$-sijojen asemasta virossa ja suomessa}

Viron ja suomen paikallissijojen suunta-aspektit eli latiivisuus (minne?), lokatiivisuus (missä?) ja separatiivisuus (mistä?) ovat vanhaa uralilaista alkuperää. Paikallissijojen eriytyminen kahdeksi vastakkaiseksi sarjaksi, ulko- ja sisäpaikallissijoiksi, on nuorempi ilmiö ja palautuu korkeintaan myöhäiskantasuomeen (Alhoniemi 1979: 89-90; Rätsep 1979: 27, 51). Viron ja suomen paikallissijojen kielihistoriallisessa kehityksessä ja myös nykytehtävissä - varsinkin keskeisimmässä eli lokaalisten suhteiden ilmaisemisessa - on odotetusti paljon yhtäläisyyksiä (ks. myös Uuspõld 1992). Viro ja suomi ovat erilliskehityksensä aikana kuitenkin etääntyneet niin paljon, että olisi yllättävää, jos paikallissijojen funktioissa ei esiintyisi mitään poikkeavaa. Eroja siis on, ja kielenoppijan näkökulmasta ne ovat suurimmaksi osaksi sellaisia, joista on vaikea esittää yleistyksiä. Poikkeustapaukset pitää siis opetella ulkoa, samalla tavalla kuin esimerkiksi rektiotkin.

Paikallissijojen $s$-sijoja pidetään $l$-sijoja vanhempina. $s$-sijat ovatkin molemmissa kielissä hallitsevia lokaalisuuden primääreinä ilmaisimina. Esimerkiksi suomenkielisissä teksteissä yleisimpiä paikallissijoja ovat illatiivi ja inessiivi, mutta $l$-sijojen, ablatiivin ja allatiivin, frekvenssi on jopa alhaisempi kuin abstraktilla paikallissijalla essiivillä (ISK 2004: 1179, 1187). Alho Alhoniemi (1979) on todennut, että s-sijojen keskeisestä asemasta kertoo myös se, että interrogatiivipronominilla on lokaalisessa käytössä - siis tapauksissa, joissa kysytään olion sijaintia 
tai jonkin tekopaikkaa sinänsä - vain sisäpaikallissijaiset muodot missä, mistä, mihin minne, virossa vastaavasti kus, kust, kuhu (ib. 90).

$s$ - ja $l$-sijojen lokaalisissa funktioissa on seuraavanlainen ero: $s$-sijoja käytetään ensisijaisesti tilaa tarkoittavista substantiiveista, joissa korostuu kolmiulotteisuus. Kognitiivisessa kielitieteessä hahmotetaan $s$-sijat SÄILIÖ-skeemana. $l$-sijoja käytetään pintaa tarkoittavista substantiiveista, joissa korostuu kaksiulotteisuus. Kognitiivisen kielitieteen mukaan kyseessä on ALUSTA-skeema. (Ks. Alhoniemi 1979: 92-93; Vainik 1995: 148-150; ISK 2004: 1187-1197.) Valtavirrasta poikkeavat tapaukset on selitetty joko kielihistoriallisella traditiolla tai sillä, että $s$-sijojen käyttö perustuu niiden ikään, kuten esimerkiksi pukeutumiseen liittyvässä sanastossa: vir. panen kingad jalga, mütsi pähe, kindad kätte, rätiku kaela 'laitan kengät jalkaan, lakin päähän, hanskat käteen, huivin kaulaan' (EKG 1995: 54).

$s$-sijojen lokaalinen kenttä on suhteellisen selvästi rajattu, mutta l-sijojen käyttöön turvaudutaan silloin, kun halutaan ilmaista abstraktimpia lokaalisia tai muita suhteita (Alhoniemi 1979: 91; ISK 2004: 1187-1188; EKG 1995: 54-55). Tästä saattaa johtua myös se, että niin virossa kuin suomessakin käytetään paikannimistä ensisijaisesti sisäpaikallissijoja, mutta ulkopaikallissijoja erityisesti niistä paikannimistä, joiden loppuosana on konkreettisen merkityksen omaava luonto- tai maastotermi, kuten kivi, mäki, joki, maa, suo jne., esimerkiksi vir. Alatskivil, sm. Seinäjoella. Ulkopaikallissija tekee paikannimn konkreettisesta maastotermistä riittävän abstraktin ja häivyttää ei-toivotun konkreettisen tulkinnan.

l-sijat kehittyivät itämerensuomalaisiin kieliin ikään kuin kielen ylellisyytenä, koska enää ei ollut ensisijaista tarvetta lokaalisuuden ilmaisemiseen. $l$-sijojen semanttinen kuormitus olikin aluksi oletettavasti aika vähäistä, mikä mahdollisti niiden käyttöönoton mitä erilaisimpien abstraktien suhteiden (aika, habitiivisuus, rooli, elollisuus vs. elottomuus jne.) ilmaisemiseksi. Viron kielessä hyödynnettiin l-sijoja kielen myöhemmässä kehitysvaiheessa lisäksi ahkerasti käännöksissä, varsinkin venäjästä ja saksasta lainattujen rakenteiden vironnoksissa, esimerkiksi 
midagi südamel (Ades) olema, saks etw auf dem Hezen haben "olla jotain sydämmellä"1. l-sijojen käyttö saavutti Virossa suuren suosion 1930-luvulla, jolloin niillä yritettiin jopa liioitellusti korvata viroon vakiintuneita postpositorakenteita, kuten esimerkiksi astus minule "astui minulle" pro astus minu juurde 'astui luokseni', linn asub Vahemerel "kaupunki sijaitsee Välimerellä" pro linn asub Vahemere ääres 'kaupunki sijaitsee Välimeren rannalla'. Johannes Aavik paheksui l-sijojen liiallista käyttöä ja totesi, ettei $l$-sijojen suosiminen tee kielenkäytöstä yhtään sen sivistyneempää eikä runollisempaa. Ilmiölle hän antoi nimeen l-tõbi 'l-tauti' (Aavik 1936: 101). Viron kielen ohjailu jatkoi siitä huolimatta postpositiorakenteiden kitkemistä kirjakielestä (vrt. esim. Remmel ym. 1959: 177).

Viron ja suomen paikallissijojen semanttisten ryhmien vertailu viittaa tendenssiin, jonka mukaan virossa suositaan ulkopaikallissijoja tai postpositiorakenteita ja suomessa sisäpaikallissijoja (ks. myös Uuspõld 1992: 81):

Postmargil on president.

Sellel pildil olen viieaastane.

Ema tõi toidu lauale.

Puudel on veel lehti.

Sääsed olid kogu aeg meie kallal.
Postimerkissä on presidentti.

Tässä kuvassa olen viisivuotias.

Äiti toi ruoan pöytään.

Puissa on vielä lehtiä.

Hyttyset olivat koko ajan kimpussamme.

Esimerkiksi suomen kutittaa+elat. -rakenne kutittaa vatsasta, jalasta, kainalosta jne. kääntyy viroksi postpositiorakenteella kõditada talla/ kaenla alt; kõhu/selja pealt jne. "kudittaa tallan/kainalon alta; vatsan/ selän päältä”. Havaintoni koskee viron ja suomen yleiskieltä, mutta suomen murteissa toteutumat voivat olla aihepiireittäin erilaiset. Jaakko Sivula on esimerkiksi tutkimuksessaan havainnut, että kiimatermistössä suomen itämurteet suosivat ulkopaikallissijoja ja länsimurteet sisäpaikallissijoja (1989: 278). Syitä sijasarjojen poikkeavaan hyödyntämiseen virossa ja suomessa on ilmeisesti useita: a) erilaiset kielimallit

Lainausmerkeissä esitetyt käännökset ovat sanan ja morfeemin tarkkuudella, puolilainausmerkeissä on merkityksen selitys. 
(virossa saksa, suomessa ruotsi); b) suomen kielen konservatiivisuus (vrt. sisäpaikallissijat ovat vanhempia ja ulkopaikallissijat nuorempia); c) kirjakielen voimakas normittaminen ja ohjailu lienee ollut varsinkin virossa oleellinen tekijä 1900-luvun ensimmäisellä puoliskolla. Esimerkiksi Aavik, joka muuten otti mielellään mallia suomen kielestä, saattoi pitää s-sijan käyttöä joissakin tapauksissa huonona suomenmukaisuutena ja suositella itsekin mieluummin $l$-sijan käyttöä, kuten esimerkiksi vir. suhtub sellele pro suhtub sellesse 'suhtautuu siihen' (Aavik 1936). Tässä yksittäistapauksessa virossa jäi kuitenkin käyttöön $s$-sija.

\section{Paikallissijojen merkityksiä, jotka virosta tai suomesta puuttuvat}

Tässä kiinnitän lyhyesti huomiota sellaisiin paikallissijojen merkityksiin, joita jommassakummassa kielessä ei ilmaista paikallissijoilla. Monesti poikkeavuudet ovat vain lekseemikohtaisia, jolloin sijan valinta voi riippua lainasuhteista, verbin rektiosta, erilaisista analogioista tai sattumasta. Niiden perusteella on vaikea tehdä yleistyksiä. Nostan esille muutamia merkitysryhmiä, jotka ovat produktiivisia ja joiden käännökset luovat laajemman taustan toimintaa ja toiminnan kohdetta kuvaavien rakenteiden tarkastelulle.

Suomen kielessä esiintyvät, mutta viron paikallissijoilta puuttuvat seuraavat merkitykset:

1) Suomen kielen adessiivilla ilmaistaan toimintaa, jota ei tarkemmin rajata tai jonka tarkkaa sisältöä ei tiedetä, esimerkiksi hän on kaupungilla vs. hän on kaupungissa 'hän on kaupungissa'. Olen huomannut, että virolaiset suomen oppijat eivät hahmota kyseistä suomen adessiivin käyttöä produktiiviseksi, koska virossa ei ole vastaavaa sijaoppositiota. Kuvaavaa kuitenkin on, että viroksi tällainen merkitys kääntyy pealrakenteella eli hän on kaupungilla on viroksi ta on linna peal "hän on kaupungin päällä”. Käännöksessä voidaan toiminnan epämääräisyys ilmaista muusta kontekstista riippuen erilaisilla verbeillä, esim. läks linna kolama, uitama, jalutama 'meni kaupungille kuljeskelemaan, luu- 
haamaan, kävelylle’. Suomen kielessä adessiivilla ilmaistavan toiminnan sumeus tulee ehkä vielä paremmin esille instituutiota tarkoittavien substantiivien yhteydessä. Niiden kohdalla sisäpaikallissija tarkoittaa olemista kyseisessä paikassa (sisätiloissa) jotakin tarkoitusta varten, joka on ominainen tuon instituution tehtävälle, ulkopaikallissija siellä olemista muuta tarkoitusta varten, esim. äiti on toimistolla äiti on toimistossa, mutta ei tee siellä toimistovirkailijan työtä, vaan on mahdollisesti asioimassa tai ehkä keskustelemassa toimistovirkailijan kanssa tms.' (ISK 2004: 1192). Ilmaisun vironnos taas hyödyntää peal-rakennetta ema on kontori peal “äiti on konttorin päällä”.

2) Suomen kielen ulkopaikallissijoilla ilmaistaan elollista omistajaa ja sisäpaikallissijoilla kuuluvuutta, ts. elotonta "omistajaa”. Täysin poikkeuksetonta tämä tendenssi ei ole, mutta habitiivisissa ilmauksissa elollista omistajaa ilmaistaan pääsääntöisesti $l$-sijoilla, esimerkiksi lapsella on avain. Sisäpaikallissijoilla ilmaistaan kuulumis- ja sisältyvyyssuhteita, esimerkiksi housuissa on tasku; talossa on suuret ikkunat. Virossa habitiivisuussuhteet ilmaistaan riippumatta entiteetin elollisuudesta tai elottomuudesta vain ulkopaikallissijoilla, sisäpaikallissijojen tulkinta on konkreettinen ja lokatiivinen, esim. kotil on lukk "kassilla on vetoketju" eli 'kassissa on vetoketju' ja kotis on lukk 'vetoketju on kassissa'.

Tuntuu siltä, ettei viron paikallissijoille ja sijajärjestelmien vastakkainasettelulle ole kehittynyt yhtä selkeitä ja produktiivisia merkityskenttiä kuin suomen kielessä. Virosta voidaan nostaa esille muutamat rajalliset käyttöalueet:

1) Materiaali tai aine, josta jotakin on tehty tai josta jokin koostuu, ilmaistaan virossa elatiivilla, esimerkiksi paat on plastmassist $\sim$ plastmassist paat 'vene on muovia', puust lusikas 'puulusikka'. Suomessa ilmaistaan kyseinen rakenne useimmiten joko yhdyssanalla tai ' $\mathrm{X}$ on A:ta (Part)' -rakenteella. Partitiivikin on kuitenkin vanha erosija. Samaa mallia käytetään myös toimijan luonnehdinnassa, esimerkiksi tüdrukust giid tegi meie reisist huvitava "tytöstä opas teki matkastamme mielenkiintoisen” eli 'opastyttö teki matkastamme mielenkiintoisen' tai 'tyttö, joka toimii oppaanamme, teki matkastamme mielenkiintoisen'; rebasest kana- 
varas viis meilt kolm kana "ketusta kanavaras vei meiltä kolme kanaa" eli 'kanavaraskettu vei meiltä kolme kanaa'. Elollisen toimijan kohdalla viron vastaava rakenne on suomen näkökulmasta hankala eikä ole käännettävissä kovinkaan ytimekkäästi. Näiden tapausten perusteella näyttää siltä, että suomen kielessä olisi jonkinlainen pyrkimys rajata elollinen vs. eloton omistaja eri paikallissijajärjestelmien merkitystehtäviin. Tästä tarvittaisiin lisää tutkimusta.

2) Ajan ilmaisuissa käytetään virossa suomea huomattavasti enemmän ulkopaikallissijoja. Syykin on ymmärrettävä, koska ajan ilmaisussa suomessa hyödynnetään essiiviä produktiivisesti, virossa ei. Suomessa l-sijojen käyttö rajoittuu vuorokauden osiin ja vuodenaikoihin, esim. aamulla, illalla; keväällä, talvella. Virossa taas ulkopaikallissijoilla on temporaalisissa ilmauksissa keskeinen asema. Niitä käytetään kuten suomessakin vuorokauden osien yhteydessä, esimerkiksi öösel 'yöllä, ja vuodenaikojen yhteydessä, esimerkiksi suvel 'kesällä, ja lisäksi kuukausien nimissä, jos niillä on määrite, esimerkiksi kolmandal jaanuaril "kolmannella tammikuulla” (vrt jaanuaris 'tammikuussa'), viikonpäivien yhteydessä, esim. reedel "perjantailla", laajempien ajanjaksojen yhteydessä, esim. eelmisel aastal "viime+adess. vuosi + adess." ja juhlapäivien nimissä, esim. jaanipäeval "juhannuksella" jne.

\section{4. / ja s-sijojen oppositiosta}

Niin virossa kuin suomessakin on tapauksia, joissa $s$ - ja $l$-sijojen käyttö ei ole täysin vakiintunut tai joissa niiden välinen ero ei ole yksiselitteinen. Ahrens kirjoitti jo 1800-luvun kieliopissaan, että paikallissijasarjat tulee pitää pääsääntöisesti toisistaan erillään; virossa on esim. jõe ääres (iness.), mutta jõe kaldal (allat.); läks pulma (illat.), mutta läks matuksel (nykyviron muoto matusele) (allat.) (Ross 2003: 353). Joissakin ilmauksissa on kuitenkin samantekevää, kumpaa sijasarjaa käytetään, esimerkiksi rukis lööb õide õitsele "ruis puhkea kukkaan kukalle", elan Kibuvitsa tänavas tänaval "asun Kibuvitsan kadussa $\sim$ kadulla". Viimeksimainitussa rakenteessa olisi kielenhuollon näkökulmasta oikea 
vain sisäpaikallissijan käyttö, mutta ulkopaikallissijan käyttö on siitä huolimatta saanut suuren suosion. Kun kadun nimeä ei ole, on sisä- ja ulkopaikallissijan semanttinen ero suuri ja siinä ei esiinny rinnakkaista käyttöä: elan tänaval 'asun kadulla eli olen koditon'. Ahrensin aikaiset esimerkit ovat suurimmaksi osaksi nykyvirossa vakiintuneet ja suosivat vain yhtä paikallissijaa, mutta murre- ja kirjakieli saattavat edelleen hyödyntää eri sijasarjoja, esimerkiksi Kuusalun peremies kündäb pellus (iness.), vir. kirjakielessä põllul (adess.) 'pellolla'; Hanilan eina aegas, viron kirjakielessä heina ajal 'heinäaikaan' (Pajusalu ym. 2002: 113). l- ja $s$-sijojen vapaata variaatiota esiintyy runsaasti myös suomen murteissa (Onikki-Rantajääskö 2001: 56-59).

Kirjakielen ohjailu vähensi 1900-luvulla variaatiota, mutta sähköisen viestinnän ja mediakielen myötä on se havaintojeni mukaan viime vuosikymmeninä taas lisääntynyt, esimerkiksi kirjakielen unne vajuma (illat.) 'vaipua uneen' -rakenteesta on nettikirjoituksissa suosittu rakennetta unele vajuma (allat.). Ehkä tavoitteena on Aavikin olettama runollisuus; taustalla saattaa vaikutaa Lydia Koidulan runon $M u$ isamaa on minu arm virke su rüppe heidan unele "syliisi heittäydyn unelle". Toinen esimerkki verbirektion variaatiosta. Verbistä panustama on merkityksessä 'laittaa peliin, investoida' tullut mediakielessä hyvin suosittu. Suosion myötä verbin vakiintunut ulkopaikallissijainen allatiivirektio on saanut rinnalleen voimakkaasti yleistyvän illatiivin. Nettihaku tuotti 37000 tulosta, joissa molempia rektioita esiintyy melko tasaisesti, illatiivia yllättävän paljon. Ilves: Eesti peab panustama välispoliitikale (allat.) "Ilves: Viron täytyy panostaa ulkopolitiikalle" (ERR 02.02.2009); Aaviksoo: Peame panustama vaba Afganistaani arengusse (iness.) "Aaviksoo: Meidän täytyy panostaa kehitykseen” (Postimees 06.02.2008).

Kirjakielen normeilla ei aina pystykään sulkemaan pois vaihtoehtoista muotoa, varsinkaan sellaisissa tapauksissa, joissa $l$ - ja $s$-sijoilla ei juuri ole merkityseroa. Esimerkiksi viron kieliopissa todetaan, että joidenkin substantiivien kanssa on mahdollista käyttää sekä $l$ - että $s$-sijoja, eikä merkitys juuri muutu: lapsed mängisid õuel õues "lapset leikkivät pihalla pihassa"; laeval laevas oli viiskümmend reisijat "laivalla 
$\sim$ laivassa oli viisikymmentä matkustajaa"; mees võttis riiulist $\sim$ riiulilt raamatu "mies otti hyllystä hyllyltä kirjan" (EKG 1995: 55).

Suomen murteiden paikallissijaisista olotilan ilmauksista Tiina Onikki-Rantajääskö on todennut, että sisä- ja ulkosijan ero on niissä neutraalistunut. Lekseemeittäin konventio on kiteyttänyt käyttöön jommankumman sijasarjan, mutta joissakin tapauksissa sijat ovat vapaassa vaihtelussa. Sisä- ja ulkosijan keskinäistä jakaumaa paikallissijaisissa olotilanilmauksissa ei selitä mikään selvä yksittäinen syy.

Suomen yleiskielen ohjailussa pyritään käsittääkseni selkeämpään rajanvetoon ja eri sijasarjat varataan eri merkitysalueille. Osa selityksistä pätee myös viroon. Isossa suomen kieliopissa todetaan seuraavaa: "Kun entiteetillä on sekä selvä ulkopinta että esim. reunoin erottuva sisäpuoli, sisäpaikallissijaisessa ilmauksessa korostuu oleminen reunojen tms. sisässä ja ulkopaikallissijaisessa oleminen vaakatasoisella pinnalla, esim. muutoin on vain ruskistettu paistinpannussa vehnäjauhoja, makkarat piti ensin pannulla ruskistaa; mies röhnötti tuolissa, isä istui tuolilla; istui sängyssä silmät selällään, makasi sängyllä liikkumatta jne.” (ISK 2001: 1191.)

Virossa ei rajanveto ole yhtä selkeä: pannulla paistaminen ilmaistaan vain $l$-sijoilla, yleisnimitys tuoli vaatii aina ulkopaikallissijan, mutta kiiktool ja tugitool 'keinutuoli' ja 'nojatuoli' vaativat sisäpaikallissijan, koska niiden "sisällä"²] voi tosiaankin istua.

\section{Toimintaa ja toiminnan kohdetta kuvaavat rakenteet virossa ja suomessa}

Tunnettu esimerkki sijajärjestelmien vastakkaisesta käytöstä suomessa ja virossa ovat keräämistä, saalistamista ja poimimista kuvaavat ilmaukset, joissa toimintaa kuvaavalla sanalla on myös toiminnan kohteen merkitys, kuten esimerkiksi:

\footnotetext{
2 Merkillistä, että tässä sisä-vartaloinen adverbi suosii ulkopaikallissijoja, ks. myös Ojutkangas 2008: 382-400. 
viron minna kalale, seenele, marjule, mustikale, vaarikale, jahile, heinale jne.

suomen mennä kalaan, sieneen, marjaan, mustikkaan jne.

Viron uusimmassa kieliopissa (EKG 1995: 55) todetaan, että paikallissijojen keskinäinen distribuutio on satunnaista sellaisten substantiivien kohdalla, joilla ei ole konkreettista paikan merkitystä, mutta jotka paikallissijaisina ilmaisevat abstraktia paikkaa. Siinä yhteydessä annetut esimerkit ovat melko kirjavia: Olime siis kõik puhkusel "olimme silloin kaikki lomalla"; Ma hilinen rongile "myöhästyn junalle"; Mees läks kalale "mies lähti kalalle"; Küsimus pandi hääletusele "kysymys pantiin äänestykselle”. Abstraktin lokaalisuuden lisäksi esimerkkiaineistossa ei näytä olevan muuta yhteistä merkityspiirrettä.

Isossa suomen kieliopissa on pyritty hahmottamaan kokonaisuuksia ja esittämään yleistyksiä myös suppeampien ja epäproduktiivisten aihepiirien ryhmistä. Tilan ja toiminnan alaryhmästä on todettu, että toimintaa tai tekemistä tarkoittavan substantiivin sisältävät lausekkeet ovat yleensä sisäpaikallissijaisia silloin, kun kyse on jonkin keräämisestä tai saalistamisesta, ja ulkopaikallissijaisia, kun kyse on jollakin toimimisesta, jonkin nauttimisesta tai sellaisesta toiminnasta tai teosta, jossa ollaan jonkin äärellä, esimerkiksi mennä kalaan marjaan $\sim$ sieneen 'keräämään ko. entiteettiä'(ISK 2004: 1195-1196).

Ene Vainik on tutkimuksessaan viron ulkopaikallissijojen semantiikasta todennut, että vastavanlaiset viron ilmaisut kuuluvat ryhmään, jossa tapahtumaan viitataan sen osan kautta (pars pro toto). Kiintopisteenä (landmark) toimiva sana voi tarkoittaa muun muassa toiminnan kohdetta, esimerkiksi lapsed läksid seenele, marjule, vaarikale (Vainik 1995: 113-114). Tiina Onikki-Rantajääskö tarkastelee näitä rakenteita olotilanilmausten yhteydessä ja erottaa ilmaukset, joissa patientti on keräämisen, pyy(dys)tämisen tai sadonkorjuun kohde, tyypiltään keruuskeemaksi, esimerkiksi Sieneen on ainakin yhtä suuri syy lähteä kuin kalaan tai karpaloon (Onikki-Rantajäskö 2001: 75). OnikkiRantajääskö toteaa, että ryhmä on varsin sulkeinen ja että sisäsija- 
ilmauksia voidaan luontevimmin muodostaa marjojen nimistä, yleisemmin metsästä kerättävistä marjoista: olla puolukassa, mustikassa, muuraimessa; käydä hillassa; lähteä suolle lakkaan; olla karpalossa, vatussa, ?vadelmassa, mansikassa, ?pihlajanmarjassa, ?tyrni-marjassa. Ilmaisutyyppi ei näytä hyväksyvän yhdyssanoja. Yhteistä keruuskeeman patienteille on se, että ne hankitaan tai noudetaan (Setälä 1942: 59; Onikki-Rantajääskö 2001: 75-76).

Ilmaisujen monipuolisuus on suomen nykykielessä supistunut melko rajalliseksi, mutta vanhempien suomen kielioppien esimerkkien valossa malli on ollut aikaisemmin varsin produktiivinen ja sitä on käytetty keräämistä ja saalistamista merkitsevistä entiteeteistä, esimerkiksi lähteä lehteen 'mennä lehtiä riipimään' (Becker 1824: 212-213); väki on elossa 'olla elonkorjuussa eli viljaa poimimassa' (Koskinen 1860: 39); hän on jyvässä (Setälä 1942: 59), oravassa ollessani 'kun olin oravia metsästämässä’ (Setälä 1883: 68). Huomionarvoista on myös se, että suomen murteissa näyttävät käytössä olleen sekä ulko- että sisäpaikallissijaiset ilmaukset. Hannikainen (1886) esittää esimerkiksi seuraavat parit: heinällä heinässä, kalassa kalalla, juoksussa juoksulla, toimituksissa toimituksilla. Hän kytkee eri sijat eri merkitysalueisiin. Sisäsijat liittyvät määräpaikkaan: heinälatoon, josta noudetaan heinää, kalapaikkaan, jossa kalastetaan, juoksuasentoon jne., mutta ulkosijat ilmaisevat liikkumista määrämättömällä alalla: heinänteossa niityllä, kalavesillä, ulkona juoksemassa. Hannikaisen mukaan sisäpaikallissijoihin pannaan sen kollektiiviesineen nimi, jonka sisäpuolella eli piirissä työn tekijän arvellaan olevan toimessa. Ulkosijaa voidaan käyttää myös äärellä olon merkityksestä silloin, kun kyse on toiminnan välineestä tai kohteesta olla nuotalla, mudalla 'mutahaudan äärellä mutaa hakemassa'. (Hannikainen 1886: 51-57.)

Onikki-Rantajääskö on todennut olevan ilmeistä, että Hannikainen on halunnut nähdä eron selvempänä kuin se monissa murteissa on ja millaiseksi se on vakiintunut yleiskieleen, esim. metsällä tunnetaan nykykielessä lähinnä vain metsästämisen merkityksessä, ilmauksen heinässä NS tuntee vain heinänteon merkityksessä eikä esitä ollenkaan 
ulkosijaista muotoa heinällä. Toisaalta vanha varioiva käyttö jatkuu osin edelleenkin, selvimmin ilmauksissa kalalla ja kalassa, joita käytetään synonyymisesti vailla sijainnin määräisyyttä tarkentavaa merkitystä. (Onikki-Rantajääskö 2001: 58-59.)

Viron nykykielessä käytössä olevat ilmaukset näyttäisivät olevan monipuolisempia: marjojen nimistä suositaan kuten suomessakin metsästä ja suolta poimittavia marjoja, mutta niiden lisäksi käytetään saman mallin mukaisesti myös muita metsästämiseen, pyydystämiseen ja keräämiseen liittyviä substantiiveja, esimerkiksi minna vähile "mennä ravulle" eli 'ravustamaan', jahile "metsästykselle" eli 'metsästämään', pähklile "pähkinälle", heinale "heinälle” eli 'heinäntekoon, heinänkorjuuseen'. Toiminnan kohdetta kuvaaville rakenteille on yhteistä se, että kerättävät, poimittavat tai saalistettavat kohteet sijaitsevat jossakin kauempana kotipiiristä, niitä käydään hakemassa ja niiden perään pitää lähteä.

Kuten suomessa, niin virossakin on ainakin kielioppien esimerkkien valossa niistä ilmauksista ollut käytössä sekä sisä- että paikallissijaiset ilmaukset. Esimerkiksi Ahrens toteaa kieliopissaan, että joissakin tapauksissa on samantekevää, käytetäänkö sisä- tai ulkopaikallissijoja, esim. käib pähklis, marjus, seenis, wähis või pähklil, marjul, seenil, wähil. (Ross 2003: 352). Wiedemannin (1875) kieliopissa on korostettu, että mikäli käytetään muotoa läks seenile, käytetään varmasti myös muotoja on seenil, tuli seenilt. Mikäli käytössä on muoto on seenis, ovat muut muodot läks seeni, tuli seenist. Käytössä on siis kaksi sijasarjaa, mutta sekaisin niitä ei käytetä. Wiedemann korostaa, että molemmat ilmaisut merkitsevät samaa (Wiedemann 1875: 340-341).

Miksi virossa ja suomessa ilmaistaan sama asia eri keinoin? Saalistaminen ja keräily ovat ilmiönä hyvin vanhoja. Jollakin tavoin niistä on varmasti puhuttu jo ennen kuin sisäpaikallissijat kehittyivät omaksi ryhmäkseen. s-sijojen ikä ei välttämättä tarkoita, että sisäpaikallissijat olisivat kyseisessä tehtävässä alkukantaisempia, varsinkaan kun huomioidaan se, että sekä suomen että viron murteissa on ollut selvästi kahtalaista käyttöä. Synkronisella tasolla pitää ehkä tyytyä toteamaan, että kyseessä on ollut sattuma, mutta todennäköisesti kummassakin 
kielessä on vaikuttanut jokin analogia, sattumalta erilainen virossa ja suomessa.

Oma käsitykseni on, että mallina ovat olleet hakemista ja työntekoa kuvaavat ilmaisut ja morfologisina mallirakenteina postpositiorakenteet tai yhdyssanat. Postposition tai yhdyssanan sija-analogia on vaikuttanut nykyisen rakenteen sijanvalintaan. Siitä on viitteitä kansanrunoudessa ja yllättävästi myös kielioppien esimerkkiaineistojen selityksissä (vrt. edellä esitettyjä esimerkkilauseiden selityksiä).

Viron kansanrunossa “Tähemõrsja” 'Tähtimorsian' on seuraava säkeistö:

ühe mina saadin marjamaale, 'toisen minä lähetin marjamaalle' teise saadin karjamaale, 'toisen lähetin laidunmaalle' kolmanda kala järele 'kolmannen kalaan' [---]

ei tuld koju kala järelta 'ei tullut kotiin kalasta'

(Tedre 1969: 24)

Postpositiorakenteiden suosiminen virossa kävi kuvaavasti ilmi myös suomen olla kaupungilla -rakenteiden vironnoksista olla linna peal "olla kaupungin päällä". Tuntuisi luontevalta ajatella, että kalassa, marjassa jne. ilmausten taustalla oli aluksi pelkkää hakemista ja myöhemmin työntekoa tarkoittava ilmaisu. Kuvaavaa on, että sanojen töö ja työ yhteydessä käytetään sijoja vastaavasti: vir. käia tööl "käydä työllä" ja sm. käydä töissä.

\section{Lopuksi}

Useimmat kieliopit ovat synkronisia. Normatiivisissä nykykielen kieliopeissa annetaan ohjeita kielen hyvää käyttöä varten. Yleistykset tehdään vain kielen omasta aineistosta. Kontrastiivinen tutkimus auttaa ymmärtämään miksi asiat ovat kielessä niin kuin ovat. Opetuksen ja opiskelun kannalta taustatiedot ovat antoisia. 


\section{Lähteet}

Aavik, Johannes 1936. Eesti õigekeelsuse õpik ja grammatika. Tartu.

Alhoniemi, Alho 1975. Eräistä suomen kielen paikallissijojen keskeisistä käyttötavoista. - Sananjalka 17. Turku: Suomen Kielen Seura, 5-24.

Alhoniemi, Alho 1979. Suomen kielen $l$ - ja s-sijojen oppositiosta. - Kaisa Häkkinen, Jussi Kallio, Leena Kytömäki (Toim.). Sanomia. Juhlakirja Eeva Kangasmaa-Minnin 60-vuotispäiväksi 14.4.1979. Turun yliopiston suomalaisen ja yleisen kielitieteen laitoksen julkaisuja 9. Turku, 89-105.

Alhoniemi, Alho1983. Suomen kielen paikallissijojen käytöstä. - Tietolipas 93. Nykysuomen rakenne ja kehitys. Helsinki: Suomalaisen Kirjallisuuden Seura, 209-229.

Becker, Reinhold von 1824. Finsk Grammatik. Åbo: Bibel-Sällskapets tryckeri.

EKG = Erelt, Mati, Reet Kasik, Helle Metslang, Henno Rajandi, Kristiina Ross, Henn Saari, Kaja Tael, Silvi Vare 1995. Eesti keele grammatika I. Morfoloogia. Sõnamoodustus. 1995. Tallinn: Eesti Teaduste Akadeemia Eesti Keele Instituut.

ERR = Eesti Rahvusringhääling 02.02.2009.

Hannikainen, O. 1886. Työtä eli toimitusta merkitsevistä lausetavoista. - Virittäjä, 51-57.

ISK = Hakulinen, Auli, Marja Vilkuna, Riitta Korhonen, Vesa Koivisto, Tarja Riitta Heinonen, Irja Alho 2004. Iso suomen kielioppi. Suomalaisen Kirjallisuuden Seuran toimituksia 950. Helsinki: Suomalaisen Kirjallisuuden Seura.

Koskinen, Yrjö 1860. Finska språkets satslära: Ett försök. Åbo: J. W. Lillja.

Ojutkangas, Krista 2008. Mihin suomessa tarvitaan sisä-grammeja? - Virittäjä, 382-399.

Onikki-Rantajääskö, Tiina 2001. Sarjoja. Nykysuomen paikallissijaiset olotilanilmaukset kielen analogisuuden ilmentäjinä. Suomalaisen Kirjallisuuden Seuran toimituksia 817. Helsinki: Suomalaisen Kirjallisuuden Seura.

Pajusalu, Karl, Tiit Hennoste, Ellen Niit, Peeter Päll, Jüri Viikberg 2002. Eesti murded ja kohanimed. Tallinn: Eesti Keele Sihtasutus.

Remmel, Nikolai, Johannes Valgma, Elli Riikoja 1959. Eesti keele grammatika VIII-X klassile. Tallinn: Eesti Riiklik Kirjastus.

Ross, Kristiina 2003. Uue ajastu misjonilingvist. Eduard Ahrens 200. Tallinn: Eesti Keele Sihtasutus.

Rätsep, Huno 1979. Eesti keele ajalooline morfoloogia II. Tartu: Tartu Riiklik Ülikool. 
Setälä, Emil Nestor 1883. Lauseopillinen tutkimus Koillis-Satakunnan kansankielestä. Helsinki: Suomalaisen Kirjallisuuden Seura.

Setälä, Emil Nestor 1942. Suomen kielen lauseoppi oppikouluja varten. Uudistettu painos. Kirjallisuuden Seuran toimituksia 504. Helsinki: Suomalaisen Kirjallisuuden Seura.

Tedre, Ülo 1969. Eesti rahvalaulud. Tallinn: Eesti NSV teaduste Akadeemia Keele ja Kirjanduse Instituut.

Uuspõld, Ellen 1992. Sise- ja väliskohakäänded lokaaladverbiaali väljendajatena. Hannu Remes (Toim.). Lähivertailuja 6. Suomalais-virolainen kontrastiivinen seminaari Mekrijärvellä 10.-11.4.1992. Joensuu: Joensuun yliopisto, 79-84.

Vainik, Ene 1995. Eesti keele väliskohakäänete semantika kognitiivse grammatika vaatenurgast. Tallinn: Eesti Teaduste Akadeemia Eesti Keele Instituut.

Wiedemann, Ferdinand Johann 1875. Grammatik der Ehstnischen Sprache. St.-Pétersbourg.

\section{Eve Mikone}

Suomen kieli

20014 Turun yliopisto

Finland

eve.mikone@utu.fi 


\title{
Interior and exterior local cases in Estonian and Finnish
}

\author{
EVE MIKONE \\ University of Turku
}

Both Estonian and Finnish have six local cases, which divide into interior and exterior cases. From the historical point of view the interior cases are older than the exterior ones. The interior cases date back to the Proto-Uralic, whereas the exterior cases in Estonian and Finnish have a Baltic-Finnic background and are thus notably younger.

From the semantic point of view there are no peculiarities in the basic function of the interior and exterior cases. Interior cases are used with threedimensional entities and exterior cases with two-dimensional ones. However, the interior and exterior cases also differ in the level of abstraction. Exterior cases are younger and hence at the time they developed there was no urgent need to express local meanings, which left them "free" to take on various kinds of abstract meanings as, for example, time, possession, animate vs. inanimate etc.

Although Estonian and Finnish local cases have the same historical background and similar basic local meanings, there are also a lot of differences between the Estonian and Finnish local cases. Some of them involve an opposite use of the interior and exterior cases in the two languages, while some of them reveal completely different meanings current in those languages.

The aim of the article is to pinpoint the usage differences between the Estonian and Finnish local cases and to study some of them more closely.

Keywords: contrastive linguistics; language history; local cases; expression of localization; structures describing action or object of action; Estonian; Finnish 